Review

\title{
Bioprintability: Physiomechanical and Biological Requirements of Materials for 3D Bioprinting Processes
}

\author{
Andrea S. Theus ${ }^{1}$, Liqun Ning ${ }^{1}$, Boeun Hwang ${ }^{1}$, Carmen Gil ${ }^{1}{ }^{\mathbb{D}}$, Shuai Chen ${ }^{1}$, \\ Allison Wombwell ${ }^{1}$, Riya Mehta ${ }^{2}$ and Vahid Serpooshan ${ }^{1,3,4, * \mathbb{D}}$ \\ 1 Department of Biomedical Engineering, Emory University School of Medicine and Georgia Institute of \\ Technology, Atlanta, GA 30322, USA; andrea.theus@emory.edu (A.S.T.); liqun.ning@emory.edu (L.N.); \\ boeun.hwang@emory.edu (B.H.); carmen.julia.gil@emory.edu (C.G.); schen644@gatech.edu (S.C.); \\ awombwel3@gatech.edu (A.W.) \\ 2 Department of Biology, Emory University, Atlanta, GA 30322, USA; riya.mehta@emory.edu \\ 3 Department of Pediatrics, Emory University School of Medicine, Atlanta, GA 30322, USA \\ 4 Children's Healthcare of Atlanta, Atlanta, GA 30322, USA \\ * Correspondence: vahid.serpooshan@bme.gatech.edu; Tel.: 404-712-9717
}

Received: 27 August 2020; Accepted: 28 September 2020; Published: 1 October 2020

\begin{abstract}
Three-dimensional (3D) bioprinting is an additive manufacturing process that utilizes various biomaterials that either contain or interact with living cells and biological systems with the goal of fabricating functional tissue or organ mimics, which will be referred to as bioinks. These bioinks are typically hydrogel-based hybrid systems with many specific features and requirements. The characterizing and fine tuning of bioink properties before, during, and after printing are therefore essential in developing reproducible and stable bioprinted constructs. To date, myriad computational methods, mechanical testing, and rheological evaluations have been used to predict, measure, and optimize bioinks properties and their printability, but none are properly standardized. There is a lack of robust universal guidelines in the field for the evaluation and quantification of bioprintability. In this review, we introduced the concept of bioprintability and discussed the significant roles of various physiomechanical and biological processes in bioprinting fidelity. Furthermore, different quantitative and qualitative methodologies used to assess bioprintability will be reviewed, with a focus on the processes related to pre, during, and post printing. Establishing fully characterized, functional bioink solutions would be a big step towards the effective clinical applications of bioprinted products.
\end{abstract}

Keywords: bioprinting; printing fidelity; bioink; hydrogel; extrusion; printability; bioprintability; tissue engineering

\section{Introduction}

Three-dimensional (3D) bioprinting is an additive manufacturing technique, used to create complex tissue and organ structures that can support live cells and other biological factors. Several bioprinting strategies have been explored for the main goal of achieving viable functional constructs for tissue engineering applications [1]. Of these strategies, extrusion-based bioprinting has been the most applicable in the field of tissue engineering due to its facility in printing bioactive bioinks [2]. Other modalities such as inkjet, laser, and stereolithography-based bioprinting have been developed and increasingly used in tissue engineering applications over the past decade, but they typically introduce some complex functionality and at times run at a higher cost than the extrusion technique [3].

Inkjet bioprinting is a non-contact printing modality that deposits small ink droplets into a predetermined location driven by thermal or piezoelectric actuation [4]. This method is relatively 
fast and offers the high-resolution printing of single cells. Laser-based printing has the ability to print biological material such as cells, DNA, and peptides at a relatively high resolution at the microscale [5,6]. However, due to the pulsed laser source in this technique, cell viability can be compromised. Stereolithography is a bioprinting strategy that uses a photo-crosslinking light source to crosslink desired patterns from a bioink reservoir onto a movable platform [7]. This modality is highly tunable and prints in a layer-by-layer manner with relatively high fidelity and speed, depending on the scale of the desired construct. Utilizing these diverse bioprinting strategies, tissue-engineered constructs can be fabricated and tailored at rapid rates with defined, consistent structures and properties, hence providing multidisciplinary platforms for research and biological exploration.

Bioink printability, i.e., the ability to deposit/form stable and viable volumes of material, plays a critical role in the fabrication process. Characterization, tuning, and optimization of bioprintability require an in-depth understanding the flow behavior of the bioink, such as viscosity and shear thinning [8]. To date, a variety of bioink solutions have been commercialized in a variety of biomedical applications (Table 1).

Table 1. Commercially available bioinks.

\begin{tabular}{|c|c|c|c|}
\hline Product & Company & Materials & Advantages \\
\hline $\begin{array}{c}\text { CELLINK A } \\
\text { CELLINK A-RGD }\end{array}$ & $\begin{array}{l}\text { CELLINK, Gothenburg, } \\
\text { Sweden }\end{array}$ & $\begin{array}{c}\text { Alginate } \\
\text { L-arginine-Glycine-L-aspartic } \\
\text { Acid peptide }\end{array}$ & $\begin{array}{c}\text { Cartligae, bone and } \\
\text { mesenchymal stem cells, can } \\
\text { be used for drug delivery and } \\
\text { cell differentiation [10] }\end{array}$ \\
\hline $\begin{array}{l}\text { GelMA } \\
\text { Bio Conductink } \\
\text { GelMA A }\end{array}$ & $\begin{array}{l}\text { CELLINK, Gothenburg, } \\
\text { Sweden }\end{array}$ & $\begin{array}{l}\text { Gelatin methacrylate } \\
\text { GelMA and carbon nanotubes } \\
\text { Gelatin methacrylate and } \\
\text { alginate }\end{array}$ & $\begin{array}{l}\text { Designed for neural, cardiac, } \\
\text { and skeletal muscle cells, } \\
\text { facilitates electrical potential, } \\
\text { photo-crosslinkable [11] }\end{array}$ \\
\hline 3D-Bioplotter HT PCL & $\begin{array}{l}\text { EnvisionTEC, Gladeck, } \\
\text { Germany }\end{array}$ & Polycaprolactone & $\begin{array}{l}\text { Versatile thermoplastic, bone } \\
\text { and cartilage regeneration, } \\
\text { biodegradable, excellent } \\
\text { mechanical stability, allows for } \\
\text { controlled drug release [13] }\end{array}$ \\
\hline PhotoHA ${ }^{\circledR}$ & $\begin{array}{l}\text { Advanced BioMatrix, } \\
\text { Carlsbad, CA }\end{array}$ & Methacrylated hyaluronic acid & $\begin{array}{l}\text { Has been used in cartilage } \\
\text { tissue applications [14] } \\
\text { Superior cytocompatibility, }\end{array}$ \\
\hline Collagen Lifeink ${ }^{\circledR} 200$ & & Type I collagen & $\begin{array}{l}\text { supports cellular remodeling, } \\
\text { highly biomimetic [15] }\end{array}$ \\
\hline
\end{tabular}

It is a general requirement that bioinks should be flowable and deformable in order to be bioprinted along with being biocompatible and biodegradable [16]. After printing, the bioink should be stable and retain the desired shape and architecture according to the design model. Whether the crosslinking mechanisms are physical and/or chemical, the structural conservation must be compatible with living functional cells and able to sustain the duration of cell culture or in vivo biological environments [16]. The effect of bioink viscosity in 3D bioprinting has been widely studied and has been shown to be one of the most important parameters to consider in devising bioprinting strategies [17]. The review will evaluate the basic printability requirements for the successful selection of bioinks for 3D bioprinting processes. 


\section{Bioink Requirements}

Bioprinting must encompass both the qualities of typical 3D printing-reproducibility, structural integrity, and fidelity—as well as using inks that are compatible with living organisms-non-toxicity, degradability, adhesion to cells, and porosity [18-23]. Inks with living cells encapsulated, termed bioink, are in conflict as the characteristics that make a stable print, like density or viscosity, are often in direct contrast to sustaining life, as cells need a porous, compliable environment to grow and migrate [24]. Rheological requirements of the bioink vary based on the modality of the bioprinting, i.e., droplet-based or inkjet, laser-based, or extrusion-based printing, with the latter being the most common bioprinting method [20,24-26]. Inkjet bioprinting lays a continuous stream of small sized droplets to form the 3D structure. However, this process is usually time consuming and not efficient for large (clinical)-scale tissue manufacturing [22]. Laser-based bioprinting uses a precise laser beam to solidify the construct within a basin of bioink, but may damage the cells with heat [26] and is relatively slow [25]. Extrusion-based bioprinting has a morphology of a filament or string of low viscosity during the print which solidifies once on the print surface holds its shape and supports layering [22]. One main impediment in this method is that the applied extrusion pressure exposes the cells to a noticeable level of (shear) stress as they pass through the syringe and nozzle (needle) which can cause damages $[23,25,27]$. To limit this stress, the bioink must show less viscous behavior [28], but the risk of this is deformation, collapse, and pore closure which will in turn lower the fidelity and resolution [24].

Hydrogels are a common extrusion-based bioink, because they can encapsulate and support different types of cells and signaling molecules [18,25]. Natural hydrogels are more bioactive, but their synthetic counterparts tend to be more cost efficient and yield more consistent material properties [25]. Most bioinks, including hydrogels, are stabilized with crosslinking strategies to preserve the shape and mechanical integrity of the 3D-printed construct. Physical crosslinking utilizes temperature and/or molecular interactions to strengthen the bonds. Chemical crosslinking is typically mechanically stronger than physical crosslinking because it creates covalent bonds between polymer chains but poses the risk of becoming cytotoxic depending on the agent used. Enzymatic crosslinking also forms covalent bonds between polymer chains but is less controlled in the degree of crosslinking [19]. Controlling the degree of crosslinking is important in bio-implementations because it can modify the stiffness of the construct, which can be used to match the affected tissue [29].

\subsection{Tissue-Specific Bioinks and Their Requirements}

Hard tissue bioinks: hard (or calcified) tissues are the types that show mineralized, firm extracellular matrices (ECMs) in the body, including different types of bone, tooth enamel, dentin, and cementum [30]. Bone tissues have the strongest mechanical properties in the human body, with the typical stiffness of cortical bone being about $100 \mathrm{MPa}$ and that of cancellous bone being about 3-4 MPa [31]. Materials with high concentration and high viscosity, including ceramics, poly(caprolactone) (PCL), polylactic acid (PLA), beta tricalcium phosphate ( $\beta$-TCP), have been used to generate bioinks for bone tissue bioprinting [32]. However, as most thermoplastic materials require a high processing temperature and do not support live cell printing, hydrogel-based bioinks have become a more favorable choice of current research [33-36]. Hydrogel-based bone bioinks typically consist of a printable polymeric backbone from gelatin methacrylate (gelMA), hyaluronic acid, or alginate units that is supplemented with several bone-derived and/or osteogenic minerals and factors, such as beta-tricalcium phosphate ( $\beta$-TCP), transforming growth factor- $\beta$ (TGF- $\beta)$, and bone morphogenetic proteins (BMPs) [34,37].

In addition to mechanical strength, bone tissue mimics should replicate the native tissue microstructure and osteoconductivity to support the vascularization of the printed implants. Factors such as osteoinduction and osteopromotion have a great impact on developing bioprinted functional bone scaffolds. The recruitment of immature bone cells in bioprinted constructs and their stimulation can lead to the formation of preosteoblasts, which can in turn induce osteogenesis, a vital part in the bone healing process [38]. Therefore, biological molecules such as BMP and growth factors (VEGF, 
TGF, RGDs) are often added into the bioinks to induce bone signaling. Mineral particles including silica, borate, calcium and phosphate are also blended with ECM components and multiple types of cells, such as osteoblasts, mesenchymal stem cells (MSCs), and endothelial cells (ECs), in the bioink to promote osteoinduction and to replicate the dynamic bone microenvironment $[33,39,40]$. In addition, to facilitate the characterization and functional evaluation of the printed bone grafts, radioactive pharmaceuticals ${ }^{99} \mathrm{~m} \mathrm{C}$ and ${ }^{18} \mathrm{~F}$ have been reportedly used to label BMP-2 in bioinks to enhance the detectability of bone repair and regeneration in single photon emission CT (SPECT) and positron emission tomography (PET) imaging [41-43].

Soft tissue bioinks: the bioprinting of soft tissues such as neural, lung and cardiac tissues has distinct and specific requirements for the bioinks. Hydrogel-based bioinks which show relatively low shear stress levels under modest pressure are commonly used for their ideal printing fidelity and capability to maintain in vitro and in vivo cell viability [44-48]. Vascularization is a critical consideration for the bioprinting of many tissues, particularly for cardiac tissues, due to the notably high blood vessel density [49-51]. Sacrificial inks such as pluronic and gelatin are often incorporated in the printing process to create hollow channels at diameters ranging from micrometers (capillaries) to centimeters (arteries). Optimal cardiac-specific bioinks should exhibit an elastic modulus ranging from 1 to $16 \mathrm{kPa}$ according to the contractile function of the cardiomyocytes (CMs), and should support the matrix remodeling by the printed cells to achieve intracellular connectivity and high packing density [52-58]. Therefore, fast-acting crosslinking reagents with negligible cytotoxicity have been included in the bioinks to facilitate gentle crosslinking processes and to provide tunable mechanical properties and degradation profiles of the printed constructs [59].

To achieve the specific functionalization of bioinks, biological and chemical modifications were also employed to generate optimal printable formulations. Small molecules and ECM factors such as BMP2/BMP4 and Wnt inhibitors (IWP2) are often used in cardiac tissue bioinks to promote CM regeneration [60-66]. ECM proteins such as collagen, connexins, cadherins can be incorporated to promote cell attachment, proliferation and matrix remodeling [57,67-71]. Secreted small molecules such as transforming growth factor beta (TGF $\beta$ ), interleukin (IL)-1, IL-6, tumor necrosis factor alpha $(\mathrm{TNF} \alpha)$, endothelin 1 and angiotensin II can also promote the maturation and vascularization of the printed cardiac tissues [72,73]. Different cell types including MSCs, ECs and smooth muscle cells (SMCs) can be co-encapsulated in the bioinks, along with CMs, to provide 3D scaffolding systems that closely recapitulate the complex heart tissue. A main challenge in bioprinting such highly cellularized bioinks which is a current research focus is the negative impact of large cell numbers on the rheological properties and printing fidelity [74-77]. In addition, further research is needed to design and develop non-invasive imaging modalities that enable the monitoring and evaluation of printed tissues, possibly by incorporating various contrast agents in the tissue-specific bioinks to enhance the imaging signals of magnetic resonance (MR) or computed tomography (CT) imaging [78,79].

Bioinks for other, non-cardiac, soft tissues also require specific properties to achieve both physiological relevance and bioprintability. For instance, hepatic lobules have a complex organization of hepatocytes, hepatic stellate cells, and ECM. Thus, liver bioinks are required to contain functional ECM components, such as collagen type I, to allow for native cell interaction, reorganization, and liver function maintenance [80,81]. Neural tissue bioprinting employs bioinks with ideal conductivity, biological cues, and growth factors, including VEGF, for better neural cell growth and differentiation. Lung tissue bioprinting might combine multiple bioinks in order to create the air-blood barrier architecture, while skin bioinks need to support the co-culture of various cell types to recapitulate the multi-layered tissue structure [82,83].

\subsection{Specific Bioink Requirements for Clinical Applications}

The patient specificity of bioengineered implants has been increasingly designed and examined in various tissue engineering and regenerative medicine applications. The coupling of the 3D bioprinting technologies with advanced medical imaging modalities, such as MR and CT, have enabled major 
advancements in the fields of precision and personalized medicine [84]. For extensive use in clinical applications, the bioink material, like other implant biomaterials, must demonstrate high levels of biocompatibility, inertness, mechanical stability, and the ability to be remodeled by cells. There are already many identified clinical applications for 3D printing and bioprinting, especially in orthopedics, orthodontics, and other hard tissue applications. Biomaterials such as PLA and PCL are mainly utilized as bioinks in the clinical printing applications, due to their excellent mechanical properties, biocompatibility, and degradation rate [85]. There is, however, a demand for the development of highly tunable and versatile novel bioinks that can be used in soft tissue applications. Bioinks that contain cellular and antigenic components at times often elicit an immune response [86]. Tissue decellularization has been used as an effective method to prepare highly bioactive, patient-specific bioinks for various tissue bioprinting applications [87]. Naturally derived polymers such as alginate, fibrin, HA, collagen, and gelatin are highly printable using extrusion-based bioprinting. They offer a low donor-site morbidity and invoke a low immune response [88]. However, in vivo, they often undergo rapid degradation and/or remodeling which decreases their mechanical stability and fidelity over time.

\section{Printability and Bioprintability}

In $3 \mathrm{D}$ printing, printability generally refers to the ability of a material to be fabricated in a layer-by-layer sequence into a 3D object with well controlled design [89]. For biomedical applications, further criteria are needed to consider a material for 3D fabrication since these systems need to be able to host and maintain cell proliferation. For instance, even though thermoplastic materials like thermoplastic polyurethane (TPU) and PCL are biocompatible, they have only been used as support structures which can be sacrificed post printing, since they have a high melting temperature $\left(>90^{\circ} \mathrm{C}\right)$ which would be detrimental to cell cultures [90-92]. In addition, many 3D printable synthetic polymer materials cannot be used in 3D bioprinting due to their low cell affinity [93] and high toxicity [94] which can trigger inflammatory or other adverse response in clinical application [95].

As alternatives to traditional plastics and metal inks, bioinks have been developed for specific 3D bioprinting applications with clinical targets including different artificial organs and tissues. Due to their low fabrication temperature $\left(\sim 37^{\circ} \mathrm{C}\right.$ or lower), only a limited subset of polymer materials can be used as bioinks for 3D printing processes since they need to satisfy several important criteria for printability. These include: (i) rheological properties, i.e., the ability of the material to deform, flow, and be precisely controlled to form a 3D shape [96]; (ii) viscosity [97]; and (iii) surface tension [98]. These properties are strongly dependent on the printing techniques. For instance, the printability of bioinks composed of glycerol-water solutions is determined by a combination of viscosity, surface tension, and the density of the ink fluids in the fabrication method like inkjet printing [99]. In inkjet bioprinting, it is important that the material needs to have a rheopectic behavior, thus allowing the gel-like material to form a droplet shape after ejection due to the increasing viscosity [19]. Thus, only bioinks with low viscosities in the range of $10 \mathrm{mPa} \cdot \mathrm{s}$ are desirable in this bioprinting modality [100,101].

Other bioprinting methods such as extrusion-based printing requires the bioink to exhibit thixotropy properties, i.e., reducing viscosity under applied shear stress. This requirement is mainly due to the fact that microextruder bioprinters eject larger filament-like structures than the droplet sizes (Figure 1) [26]. As a result, commonly used non-Newtonian fluids like hydrogels are the preferred bioink type for extrusion-based bioprinting [19]. Another advantage of extrusion-based bioprinting is that it can print highly viscous cell-laden bioinks by adjusting the air pressure during the pneumatic deposition $[98,102,103]$. One disadvantage of this method is that the shear thinning property of bioink can affect the cell viability during printing [104]. 
Assessing Bioink Printability

\section{Initial Screening}

(a)

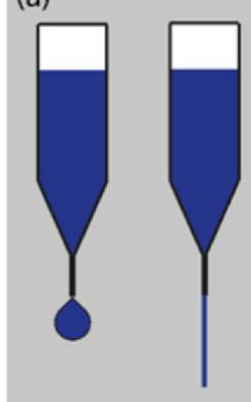

Drop or filament

/ fiber formation (b)
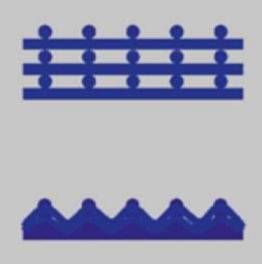

Layer stacking or merging

2. Rheological Evaluation

(a)

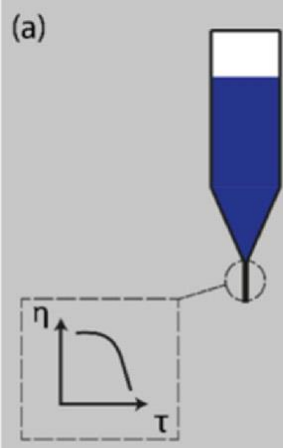

Flow initiation (b)

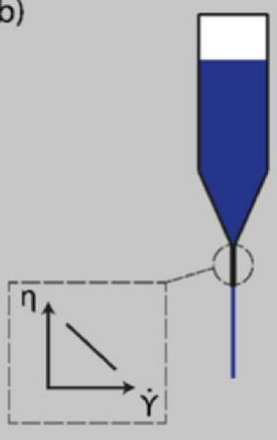

Shear thinning (c)

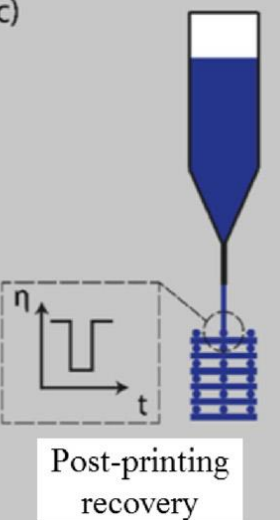

Figure 1. Schematic illustration of the workflow to assess the bioink printability for extrusion-based bioprinting [96].

Another common type of bioprinting is laser-assisted printing which can be divided into two categories: laser-induced forward transfer (LIFT), and photo-induced polymerization known as stereolithography [19]. In LIFT bioprinting, a pulsed laser is used as an energy source to induce a jet formation to the substrate. This technique requires the bioink to contain a viscosity in the range of 1 to $300 \mathrm{mPa} \cdot \mathrm{s}[5,98]$. Due to these relatively low viscosity values, it is important that the $3 \mathrm{D}$ structure is adequately crosslinked post printing to improve the mechanical integrity [5]. For stereolithographic applications, photosensitive bioinks are used [19]. An advantage of this printing technique is that it can utilize high-viscosity bioinks, while minimizing the mechanical stresses on the encapsulated cells that is typically generated by more viscous hydrogels, thus enabling higher cell viability and functionality [105].

\section{Bioprintability Assessment}

The assessment of bioprintability requires comprehensive measurements to be performed on the created constructs at multiple scales. Printing fidelity is a critical parameter that has been frequently used to describe the bioprintability of bioinks. Fidelity defines the level of structural differences between the design and actual prints [26]. In general, higher printing fidelity indicates a lower level of structural variability, demonstrating a closer match between the designed and printed structures. Lower fidelity values illustrate larger differences between the design and bioprints. Due to the liquidity and inherently low mechanical strength of hydrogel-based bioinks, it has always been challenging to build 3D hydrogel constructs with high printing fidelity [98].

Since fidelity ultimately determines the precision of the spatial control of bioink deposition, several strategies have been developed aiming to preserve or enhance the fidelity of bioinks in bioprinting processes. These strategies either rely on bioink modifications, or in situ crosslinking, or sometimes both. Bioink modification focuses on the rheological properties of the material, with the most efforts centered around viscosity [102]. A bioink with greater viscosity is likely to provide stronger mechanical support and resistance against structural deformation (e.g., due to gravity) during bioprinting, resulting in improved printing fidelity [24]. However, the excessive viscosity of bioinks often restricts the survival and functionality of cells, reducing their bioactivity when cells are encapsulated [106]. Additionally, bioinks with higher viscosity require a greater printing pressure to maintain the given printing flow rate, which in turn could cause increased cellular damages [107,108]. Bioinks with lower viscosity are more suitable for cells but they often face the issue of suboptimal printing fidelity and resolution. Therefore, a delicate compromise between the printing fidelity and cytocompatibility for a bioink should be 
established to achieve optimal tissue bioprinting efficiency (Figure 2). Higher viscosity, however, may not necessarily guarantee the high fidelity printing of soft tissue constructs [109]. Other bioink properties, such as storage $\left(G^{\prime}\right)$ and loss moduli $\left(G^{\prime \prime}\right)$, also play significant roles in bioprintability [110]. The storage modulus indicates the elastic behavior of the bioink while the loss modulus represents the liquid aspect. Typically, a bioink with a larger $G^{\prime}$ value compared to $G^{\prime \prime}$ provides a higher printing fidelity due to its increased mechanical stiffness. The bioprinting fidelity is identified according to the ratio between $G^{\prime}$ and $G^{\prime \prime}$ (also known as the loss tangent, $\delta$ ) which is highly dependent on the type of the bioink polymer [111,112].

A
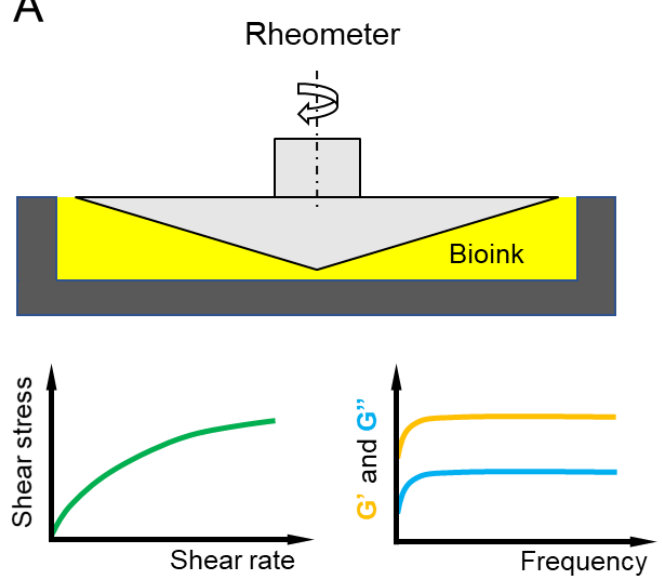

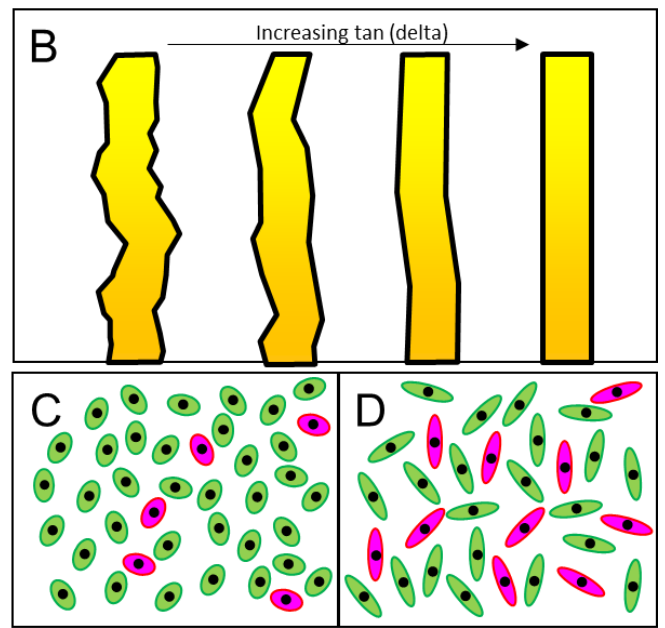

Figure 2. Rheological properties and their effects on bioprinting fidelity and cell viability. (A): Cone-and-plate rheometer and its application for evaluating the flow behavior and viscoelasticity of a bioink. (B): Influence of loss tangent on printed strand fidelity. (C-D): Influence of bioink viscosity on cell viability after bioprinting. A higher cell viability is found within lower viscosity (C) versus higher viscosity (D) bioinks. Green represents live cells and red represents dead cells.

Rheological behavior of a bioink can be regulated using both physical and chemical methods. The most straightforward way is to adjust the concentration of hydrogel materials or to blend them with other materials [113]. However, regulating the rheological behavior is usually time consuming and may not meet the biocompatibility requirement. Therefore, the second group of strategies, the in situ crosslinking methods, were used. In situ crosslinking is known as "bioprinting while crosslinking", which is used to stabilize the extruded bioinks during the printing process [114]. It significantly improves the mechanical stability of the extruded bioinks in shape, thus maintaining fidelity. Depending on the properties of bioinks, various crosslinking approaches have been tested. The crosslinking of thermosensitive hydrogels is triggered by the control of printing temperature [111]. The printing fidelity of these hydrogel bioinks relies on their mechanical properties and normally requires additional crosslinking due to their reversibility. For bioinks that can be crosslinked through ionic bonding, a crosslinking medium (bath) can be used to promote the material stabilization, which significantly reduces the spread of the bioink, thus preserving a higher printing fidelity [115]. This method normally requires a stringent adjustment of the crosslinking bath to avoid printing failures, which are introduced by the buoyance of the crosslinking agent [116].

In situ crosslinking approaches are also applicable for photo-crosslinkable bioinks [117]. During this procedure, a light source is incorporated in the printing system for initiating the polymerization. By controlling the light intensity or exposure time, the printing fidelity of bioinks can be tuned. Due to limited crosslinking rates, maintaining the fidelity of printed filaments is not ideal via in situ photo-polymerization, especially when bioinks with low viscosity are extruded [118]. The other drawback of this method is that it may introduce extra exposure to the first few deposited layers, leading to excessive stiffness and increased overall cell damage. An alternative method partially 
stabilizes the dynamic flow of bioinks within the light-permeable needle before extruding out. It creates filaments with improved stability and uniformity and allows the printing of low-viscosity hydrogel inks via the adjustment of light intensity and exposure time [119]. This unique approach requires a light permeable needle which is normally custom-made from glass or silicon. An elaborate adjustment of the light source is also necessary to ensure the uniform flow of bioink.

\subsection{Experimental Methods for Bioprinting Fidelity Assessment}

Printed filaments (strands) act as the building blocks for 3D structures in extrusion-based bioprinting, and their shape fidelity (stability) directly affects the printing fidelity of the structure in its entirety. Fidelity has been prevalently assessed through visual inspection after bioprinting-based on the microscopic evaluation of printed single filaments or layers as models for the assessment [27]. These evaluations consist of both qualitative and quantitative analyses of the geometrical features of printed models (Figure 3). The geometric characteristics that have been commonly used for fidelity evaluations include filament diameter and uniformity $[112,120]$. The diameter describes the actual size of filaments, and its similarity to the designed model can report on the bioprinting fidelity. Uniformity quantifies the length of the printed filaments and is used to determine the consistency of the bioprinted filaments in comparison to the designed model. Filaments with straight edges show higher uniformity, and hence, printing fidelity. On the contrary, printed strands with bumpy or ragged edges would yield lower bioprinting fidelity. The ability of bioprinted filaments to avoid collapse and maintaining their shape has also been identified as a particularly important index for bioprinting fidelity evaluation, when dealing with much softer materials (hydrogels) [24]. In comparison to the size and uniformity assessments, which are typically obtained from single filaments or layers in the $x-y$ horizontal plane, the ability of filament to resist gravity and falling in an overhanging structure is assessed along the $x-z$ or $y-z$ vertical planes. The bioprinting fidelity, which is quantified by the mid-span deflection angle, relies on the yield stress of filament under gravity, as well as the structural gap size. This highlights the role of the yield stress of a bioink to maintain the printed filaments from deformation as well as the structural design to reduce the collapse along the vertical direction.

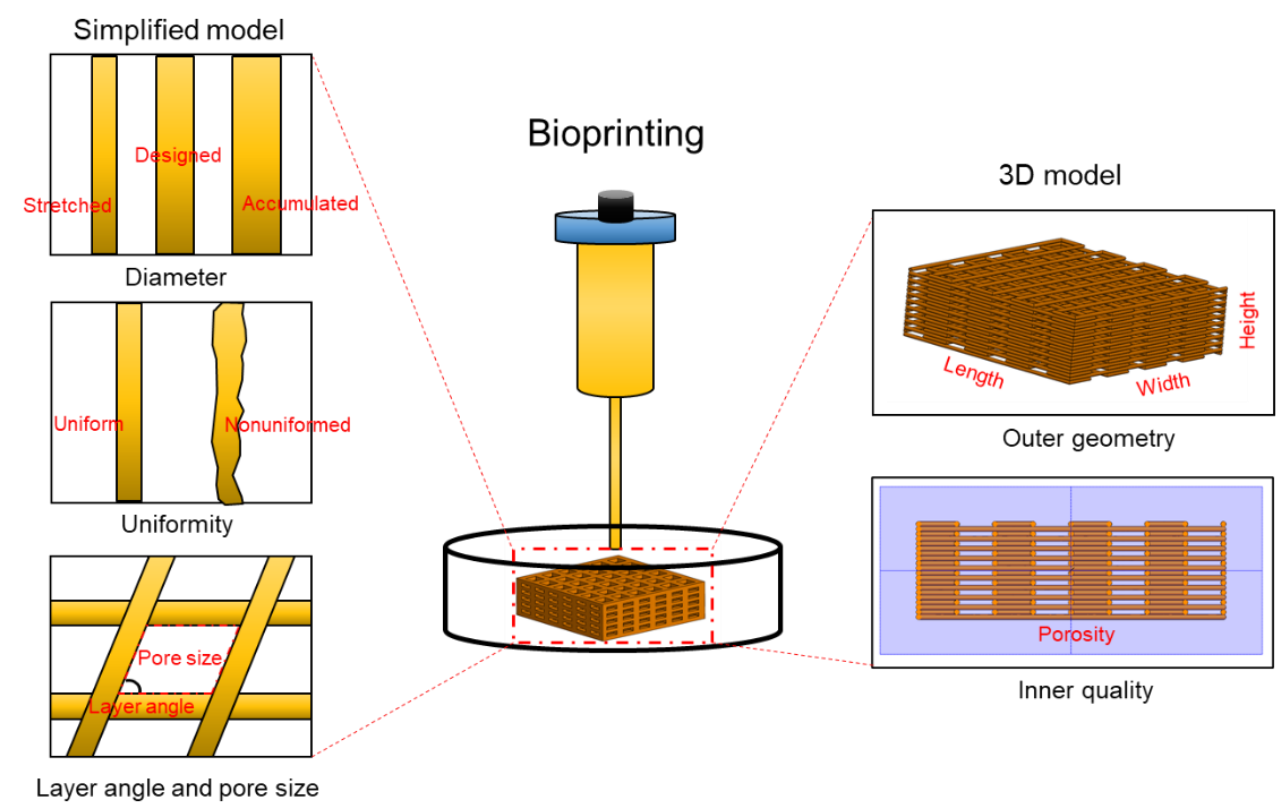

Figure 3. Geometrical parameters involved in the 3D bioprinting fidelity assessment.

The assessment of printing fidelity normally characterizes the outer geometry (e.g., height, width, and length) and the inner structure (e.g., layer angle, pore size, porosity, and printing angle) of 3D constructs. Like filament evaluation, the outer geometry is measured based on visual/microscopic 
inspection, and the printing fidelity is evaluated according to the comparison of size and shape between the bioprinted structures and their CAD designs [111,112]. Layer angle and pore size, which are created by the layer stacking, are often measured based on simplified models [22,121]. These models act as the unit element to form the entire structure following repetitive stacking, thus recapitulating the basic characteristics of actual 3D structures. However, they are not able to quantify the deformation of bioprints along the $z$ direction and are therefore unable to represent the inner quality of integrated bioprints after layer assembly. For this purpose, imaging techniques such as micro computed tomography $(\mu \mathrm{CT})$ have been used to rebuild the entire 3D structures of bioprints and analyze the porosity $[122,123]$. One major issue for this technique is that the post processing of bioprinted structures is normally required due to the relatively low density and weak X-ray attenuation of hydrogel materials [123]. Such treatment on hydrogel-based constructs may partially damage the printed structure and result in compromised accuracy. Alternatively, magnetic resonance imaging (MRI) and ultrasound imaging (UI) have shown great potential for the characterization of the hydrogel constructs [124,125]. However, both techniques face constraints to achieve high spatial reconstruction within feasible scan times. A promising imaging technique that relies on synchrotron $\mathrm{X}$-ray propagation-based imaging in combination with CT imaging (SR-PBI-CT) has recently been developed for the visualization and analysis of hydrogel-based 3D bioprinted constructs [114]. Through introducing the X-ray refraction signal, the PBI-CT technique shows promise in the visualization of low-density hydrogels due to the much larger refractive index variations. Combined with synchrotron radiation which is highly brilliant and a coherent light source, SR-PBI-CT has presented great capacity in visualizing hydrogels without the need for pre or post processing.

The printing angle is another prominent parameter that has been studied in 3D printing and bioprinting applications, mostly to test its effect on print fidelity and the ultimate tensile strength (UTS). Yao et al. discovered that the UTS of the 3D printed PLA materials decreases with the decrease in the printing angle, from $90^{\circ}$ to $0^{\circ}$ (Figure 4). They reported a significant difference in the measured UTS $(52.29 \%)$ between the $0^{\circ}$ and $90^{\circ}$ printing angles [126]. The theoretical models utilized in this study can aid in extracting important information on overall printing fidelity, to determine whether a critical defect printing angle exists.

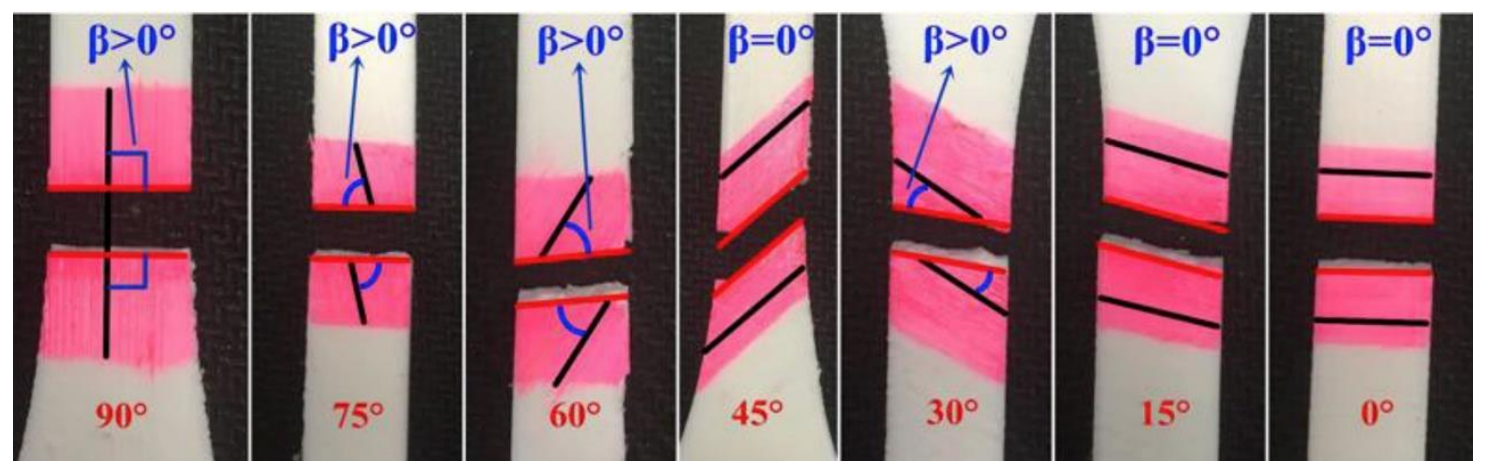

Figure 4. Ultimate tensile strength testing of polylactic acid (PLA) materials and their respective printing angles. Reprinted with permission from [126].

\subsection{Mathematical Models for Printing Fidelity Characterizations}

The size of deposited bioink filaments is not only determined by the properties of bioink and the crosslinking procedure, but also heavily depends on the printing process control [127]. To create filaments with uniform size and faithful to the designed model, most printing attempts follow a trial-and-error approach, through a series of re-adjustments of the printing process parameters, such as pressure, temperature and moving speed, and evaluating the effect on fidelity [128]. Such approaches are typically laborious and time consuming, requiring many repetitions which could also waste significant quantities of bioinks (and biological contents). To avoid these "hit or miss" strategies, 
a simple mathematical model has been developed based on the relationship between the flow rate and printing speed [129]. It is based on the prediction of the bioprinting flow rate, assuming that the bioink is incompressible [108]. If the effects of swelling and gravity can be ignored, the diameter of printed filament can be expressed as

$$
D_{p}=\sqrt{\frac{4 Q}{\pi V_{p}}}
$$

where $D_{p}$ represents the diameter of the printed filament, $Q$ is the volumetric flow rate of bioink, and $V_{p}$ represents the printing speed in horizontal plate. The large flow rate associated with lower printing speed increases the filament diameter, while a small flow rate combined with higher printing speed reduces the size. Using this equation, the geometry of printed filament can be readily regulated following the steps: 1) based on the printing resolution, selecting the printing needle with the appropriate size; 2 ) based on the needle size, establishing printing models with designed filament size; 3) adjusting the flow rate and printing speed to achieve a calculated filament size (using Equation (1)) that matches the predetermined size; and 4) bioprinting the filament and measuring its actual size. Incorporating this mathematical model into pre-printing planning could therefore help remarkably to adjust the starting printing parameters more efficiently and accurately, and to achieve the targeted bioprinting fidelity.

\section{Bioink Support for Cells and Other Biological Factors}

As 3D bioprinted constructs are often fabricated with cells, it is crucial for the bioinks to accommodate proper cell viability and function, while maintaining adequate mechanical properties for bioprintability [26]. However, many studies that investigated the effects of bioink properties suggest that there is a trade-off between the bioprintability and biocompatibility of the bioinks [27]. Often, adjusting parameters that can reinforce printability, such as increasing concentration or lowering the printing temperature, induces a harsh environment for cells to survive. Consequently, this compromise narrows the biofabrication window, imposing difficulties in the simultaneous achievement of adequate print fidelity and cell viability.

To address the challenge of cell survival during printing, several modifications have been made to bioinks to enhance their bioactivity during and after printing. Many inert hydrogels have been employed as bioinks due to their biocompatibility and mechanical similarity to the natural ECM [21]. However, the cells tend to show limited cell attachment, proliferation, and functionality in such materials [19]. This is contributed to the fact that many hydrogel bioinks, despite their non-toxic nature, lack the essential cell-supporting components such as cell binding sites. To address this issue, cell binding peptides can be incorporated into the bioinks. Studies have shown that bioinks with RGD peptides result in improved cell viability and proliferation $[130,131]$. Furthermore, hydrogels with intrinsic cell binding sites are commonly used. Such natural materials, including fibrin and gelatin-based bioinks, have inherent cell binding sites and can allow cell adhesion and proliferation without the need for modifications [98].

Bioinks can further enhance the functionality of cells by entrapping growth factors and other signaling proteins into the matrix. This allows the targeted delivery of important functional molecules to the cells, thereby creating a favorable microenvironment for specialized cellular activities [21]. For instance, Skardal et al. demonstrated the use of a hyaluronic acid and gelatin hydrogel composite infused with a liver ECM solution that contained a mixture of liver-specific growth factors [132]. Hepatocytes printed in the liver-specific hydrogel bioink were able to survive over 28 days and showed increased liver functions compared to 2D cultures.

The functionalization of bioinks with small molecules or proteins is another way to direct cellular responses via cell-material interactions. The immobilization of proteins in bioinks enables sustained exposure and subsequent responses such as stem cell differentiation [133]. In one study, dopamine was crosslinked to the gelMA bioink to promote neural differentiation (Figure 5) [134]. They found 
that gelMA functionalized with dopamine provided a favorable environment for neuronal stem cell growth and differentiation into specialized cells compared to the gelMA alone. More recently, novel methods to modify bioinks have been developed to incorporate various protein therapeutics or ECM components to control cellular activities via cell-matrix interactions $[135,136]$. These strategies are expected to further advance bioink designs to provide support for cell survival and functions.

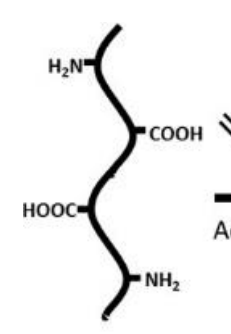

Gelatin

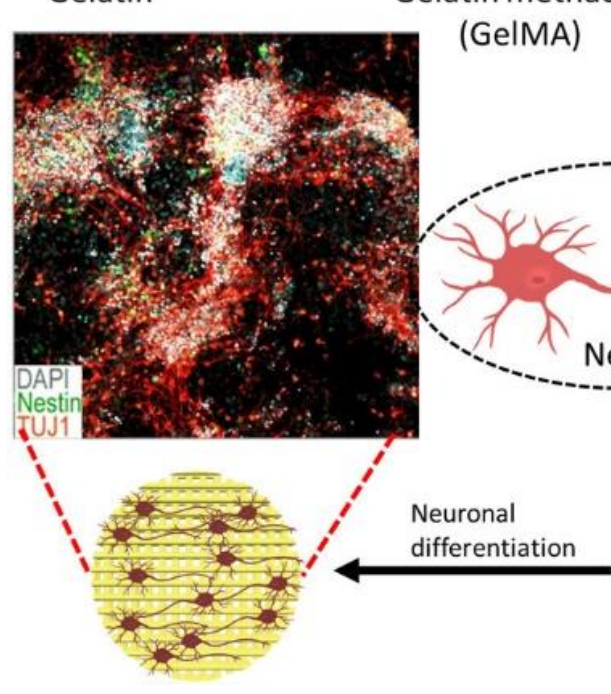

Neuronal network
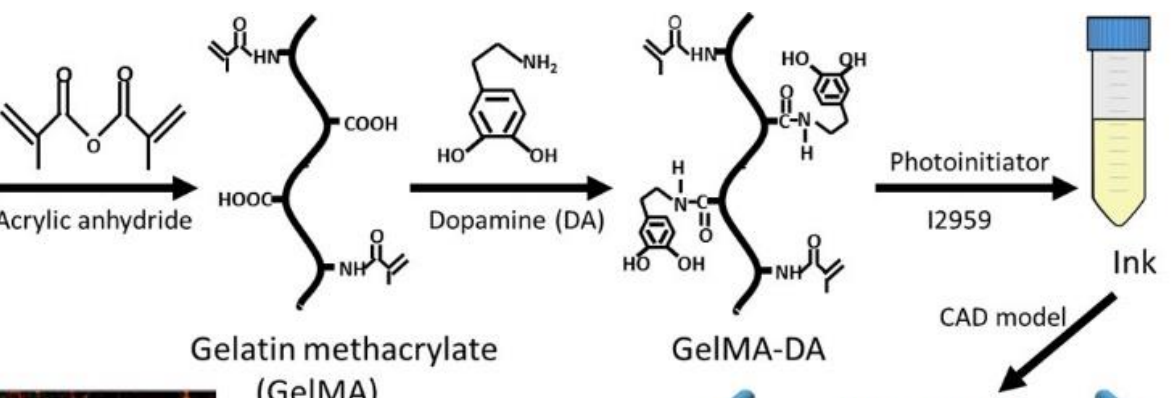

GeIMA-DA
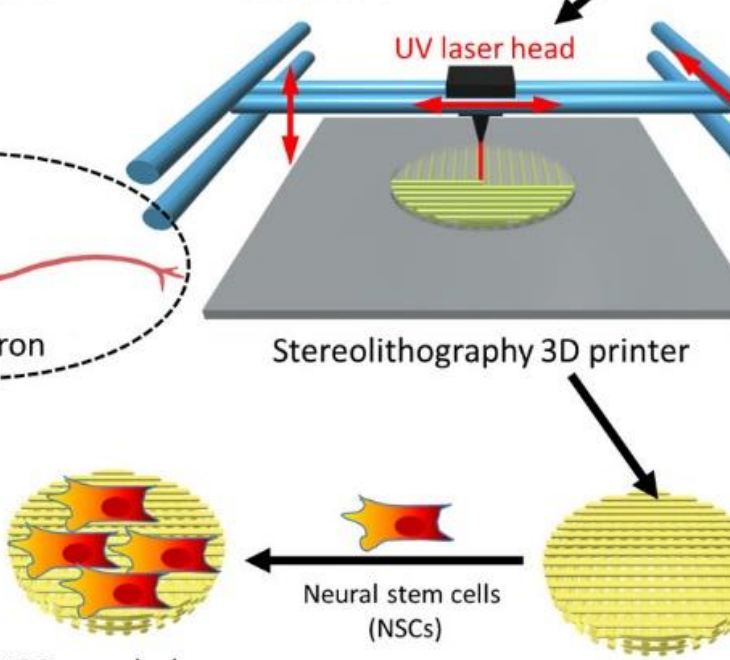

NSCs seeded on

scaffold

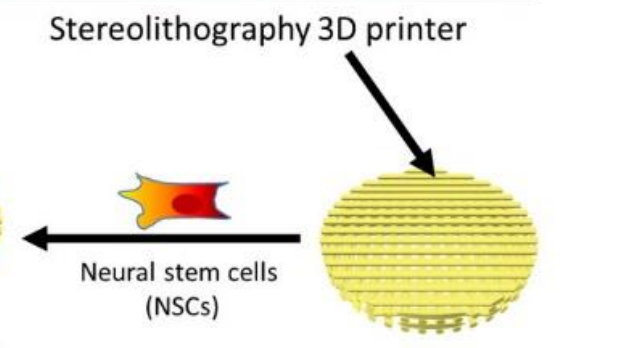

(NSCS)

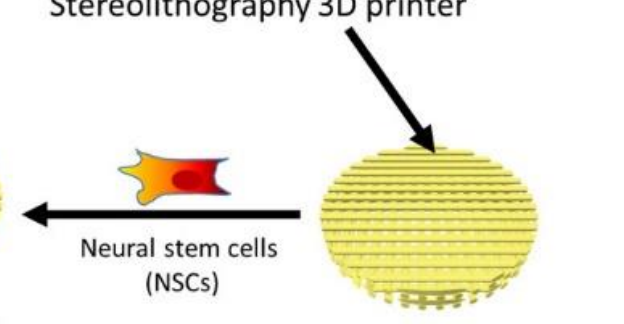

GelMA-DA scaffold

Figure 5. Schematic of a 3D bioprinted matrix utilized to promote neural cell support for tissue regeneration. Reprinted with permission from [134].

Decellularized ECM (dECM) has also gained attention as natural, potentially patient-specific bioinks retain most natural ECM constituents and growth factors. Therefore, $\mathrm{dECM}$ bioinks not only present the mechanical properties appropriate for both cell support and printing, but can also provide the microenvironment suitable for tissue-specific cellular functions [137]. In a recent study, Lee et al. printed mesenchymal stem cells and hepatocytes using a liver dECM-based bioink [138]. It was demonstrated that the liver AECM has adjustable printability and provides a biochemical environment that can stimulate stem cell differentiation as well as enhanced hepatocyte functions.

\section{Post-Print Bioink Properties}

To obtain functional bioprinted constructs with high fidelity as well as appropriate cell viability and function, the maintenance of fabricated constructs after the printing is just as important as the various considerations during the bioprinting process. The first thing to consider is preserving the shape fidelity throughout the crosslinking processes, which are traditionally categorized into chemical and physical methods. Chemical crosslinking introduces covalent bonds, while physical crosslinking is generated by electrostatic, hydrophobic or hydrogen bonding [139]. The most frequently used chemical crosslinking methods include photo-crosslinking, enzymatic linkage, amidation, and Michael addition reaction. On the one hand, supramolecular networks, thermally induced hydrogels and cyclodextrin-based materials are largely explored examples of physical crosslinking. The time of 
introducing crosslinking is critical for maintaining intricate printed structures and should be planned along with the rest of the bioprinting process control. For instance, the viscosity of materials used for inkjet bioprinting and orifice-free bioprinting is generally low and often lacks the ability to self-stand after being deposited onto the substrate. In such modalities, therefore, instantaneous crosslinking should be implemented. Extrusion-based bioprinting, on the other hand, is able to handle more viscous bioinks, with greater yield stress, that are able to sustain structural integrity for longer periods before crosslinking [98]. Higher yield stress often requires higher concentration of materials, which might compromise biocompatibility [140]. To overcome the dilemma between shape maintenance and appropriate bioink concentration, strategies such as pre crosslinking, printing into supporting self-healing hydrogel [141], and embedded bioprinting methods are proposed [142].

Aside from the timing of the crosslinking step, the degree of induced molecular interactions and entanglement affect the fidelity and outcomes of functional printed constructs by influencing hydrogel pore sizes, final mechanical properties, swelling behavior, as well as degradation rate. Thus, protocols have been proposed for measuring the crosslinking degree of printed constructs. The equilibrium swelling test is a traditional assay to determine the concentration of crosslinkers per unit volume, which could be calculated from the swelling degree by measuring the weight of the hydrogel under equilibrium swelling state and desiccated state [143]. Another candidate is the uniaxial compression test. The degree of elastically effective physical and chemical crosslinking can be calculated based on the equation derived by Flory et al. from the measured compression stress $[144,145]$. Solid state nuclear magnetic resonance (NMR) spectroscopy measurement can also be used to assess chemically effective crosslinking [143].

Another essential factor that might influence the fidelity and function of a bioprinted construct for in vitro tissue modeling or in vivo regeneration is the volumetric changes caused by swelling behavior and culture condition variations, including the temperature or $\mathrm{pH}$ changes, by which stimuli responsible hydrogels are most influenced $[146,147]$. Although these events are difficult to avoid and generally have a negative influence on the final fidelity of the printed constructs, more intricate print process design and control can help neutralize some of these effects. Shape expansion caused by swelling could be offset by incorporating temperature-sensitive polymers, such as poly(phenylene oxide), with a hydrophilic-to-hydrophobic transition. Encapsulated cells can remodel the bioprinted structure by fusion and self-assembly processes. Sun et al. developed a model that can predict the time evolution of post-printing morphological structures [148].

In terms of temporal properties in the long term, the degradation behavior of bioprinted constructs can have essential effects on their fidelity and function. Biodegradable or non-degradable materials may be considered bioinks, according to the specific applications. Bioprinted constructs typically exhibit distinct degradation rates in the in vivo versus in vitro settings $[149,150]$. Degradation can be categorized into hydrolytic, oxidative, enzymatic degradation, and photo-degradation. Material composition, $\mathrm{pH}$, enzymes, construct structure, crosslinking, weathering, physical loading, and other factors can influence the degradation rate [151]. Thus, a desired degradation rate can be adjusted by taking these parameters into consideration.

\section{Conclusions}

Three-dimensional bioprinting is a rapidly evolving additive manufacturing strategy to develop tissue constructs at the clinical and industrial scales, while providing highly tunable and reproducible functionalities. The pioneering works in this field have proven the feasibility of bioprinting a variety of biomaterials and cellular components to form rather complex tissue constructs. Although there have been expansive efforts to advance this field, the lack of standardized methods to characterize the optimal mechanical, rheological, and biological properties of bioinks have hindered particularly the in vivo and clinical applications. As the commercial availability of novel bioink formulations arises, there may be new metrics in place to aid the assessment of bioprinting fidelity. This review provided current state-of-the-art methods, together with experimental and mathematical procedures 
that have been used to analyze bioprintability and develop optimized bioink solutions for tissue-specific applications. While the experimental methods to assess and tune bioprinting fidelity typically rely on repetitive trial-and-error steps, the emerging mathematical and computational models have shown great promise in improving the efficiency and accuracy of these processes. These theoretical models, however, would still require further enhancement, for instance, to incorporate and carefully assess the cellular and biological factors involved in various bioprinting procedures.

Funding: This research was funded by the National Institute of Health (NIH) grant number R00HL127295 and Emory University School of Medicine, the Pediatric Research Alliance Pilot Grant and the Dean's Imagine, Innovate and Impact (I3) Research Award.

Conflicts of Interest: The authors declare no conflict of interest.

\section{References}

1. Papaioannou, T.G.; Manolesou, D.; Dimakakos, E.; Tsoucalas, G.; Vavuranakis, M.; Tousoulis, D. 3D Bioprinting Methods and Techniques: Applications on Artificial Blood Vessel Fabrication. Acta Cardiol. Sin. 2019, 35, 284-289.

2. Ozbolat, I.T.; Hospodiuk, M. Current advances and future perspectives in extrusion-based bioprinting. Biomaterials 2016, 76, 321-343. [CrossRef] [PubMed]

3. Sun, W.; Starly, B.; Daly, A.C.; Burdick, J.A.; Groll, J.; Skeldon, G.; Shu, W.; Sakai, Y.; Shinohara, M.; Nishikawa, M.; et al. The bioprinting roadmap. Biofabrication 2020, 12, 022002. [CrossRef] [PubMed]

4. Rider, P.; Kačarević, Ž.P.; Alkildani, S.; Retnasingh, S.; Barbeck, M. Bioprinting of tissue engineering scaffolds. J. Tissue Eng. 2018, 9, 2041731418802090. [CrossRef] [PubMed]

5. Guillotin, B.; Souquet, A.; Catros, S.; Duocastella, M.; Pippenger, B.; Bellance, S.; Bareille, R.; Remy, M.; Bordenave, L.; Amedee, J.; et al. Laser assisted bioprinting of engineered tissue with high cell density and microscale organization. Biomaterials 2010, 31, 7250-7256. [CrossRef] [PubMed]

6. Guillotin, B.; Ali, M.; Ducom, A.; Catros, S.; Keriquel, V.; Souquet, A.; Remy, M.; Fricain, J.-C.; Guillemot, F. Chapter 6-Laser-Assisted Bioprinting for Tissue Engineering. In Biofabrication Micro-and Nano-Fabrication, Printing, Patterning, and Assemblies; Forgacs, G., Sun, W., Eds.; William Andrew Publishing: Boston, MA, USA, 2013; pp. 95-118.

7. Raman, R.; Bashir, R. Chapter 6-Stereolithographic 3D Bioprinting for Biomedical Applications. In Essentials of 3D Biofabrication and Translation; Atala, A., Yoo, J.J., Eds.; Academic Press: Boston, MA, USA, 2015; pp. 89-121.

8. Dorishetty, P.; Dutta, N.K.; Choudhury, N.R. Bioprintable tough hydrogels for tissue engineering applications. Adv. Colloid Interface Sci. 2020, 281, 102163. [CrossRef]

9. Osidak, E.O.; Karalkin, P.A.; Osidak, M.S.; Parfenov, V.A.; Sivogrivov, D.E.; Pereira, F.D.A.S.; Gryadunova, A.A.; Koudan, E.V.; Khesuani, Y.D.; Kasyanov, V.A.; et al. Viscoll collagen solution as a novel bioink for direct 3D bioprinting. J. Mater. Sci. Mater. Med. 2019, 30, 31. [CrossRef]

10. Sultan, S.; Siqueira, G.; Zimmermann, T.; Mathew, A.P. 3D printing of nano-cellulosic biomaterials for medical applications. Curr. Opin. Biomed. Eng. 2017, 2, 29-34. [CrossRef]

11. Kim, S.H.; Kim, D.Y.; Lim, T.H.; Park, C.H. Silk Fibroin Bioinks for Digital Light Processing (DLP) 3D Bioprinting. In Bioinspired Biomaterials: Advances in Tissue Engineering and Regenerative Medicine; Chun, H.J., Reis, R.L., Motta, A., Khang, G., Eds.; Springer: Singapore, 2020; pp. 53-66.

12. Salinas-Fernández, S.; Santos, M.; Alonso, M.; Quintanilla, L.; Rodríguez-Cabello, J.C. Genetically engineered elastin-like recombinamers with sequence-based molecular stabilization as advanced bioinks for 3D bioprinting. Appl. Mater. Today 2020, 18, 100500. [CrossRef]

13. Diaz-Gomez, L.; Elizondo, M.E.; Koons, G.L.; Diba, M.; Chim, L.K.; Cosgriff-Hernandez, E.; Melchiorri, A.J.; Mikos, A.G. Fiber engraving for bioink bioprinting within 3D printed tissue engineering scaffolds. Bioprinting 2020, 18, e00076. [CrossRef]

14. Meinert, C.; Schrobback, K.; Hutmacher, D.W.; Klein, T.J. A novel bioreactor system for biaxial mechanical loading enhances the properties of tissue-engineered human cartilage. Sci. Rep. 2017, 7, 16997. [CrossRef] [PubMed] 
15. Maxson, E.L.; Young, M.D.; Noble, C.; Go, J.L.; Heidari, B.; Khorramirouz, R.; Morse, D.W.; Lerman, A. In vivo remodeling of a 3D-Bioprinted tissue engineered heart valve scaffold. Bioprinting 2019, 16, e00059. [CrossRef]

16. Compaan, A.M.; Christensen, K.; Huang, Y. Inkjet Bioprinting of 3D Silk Fibroin Cellular Constructs Using Sacrificial Alginate. ACS Biomater. Sci. Eng. 2017, 3, 1519-1526. [CrossRef]

17. Tirella, A.; Orsini, A.; Vozzi, G.; Ahluwalia, A. A phase diagram for microfabrication of geometrically controlled hydrogel scaffolds. Biofabrication 2009, 1, 045002. [CrossRef] [PubMed]

18. Chimene, D.; Lennox, K.K.; Kaunas, R.R.; Gaharwar, A.K. Advanced Bioinks for 3D Printing: A Materials Science Perspective. Ann. Biomed. Eng. 2016, 44, 2090-2102. [CrossRef] [PubMed]

19. Hospodiuk, M.; Dey, M.; Sosnoski, D.; Ozbolat, I.T. The bioink: A comprehensive review on bioprintable materials. Biotechnol. Adv. 2017, 35, 217-239. [CrossRef]

20. O'Connell, C.; Ren, J.; Pope, L.; Li, Y.; Mohandas, A.; Blanchard, R.; Duchi, S.; Onofrillo, C. Characterizing Bioinks for Extrusion Bioprinting: Printability and Rheology. Methods Mol. Biol. 2020, 2140, 111-133.

21. Gungor-Ozkerim, P.S.; Inci, I.; Zhang, Y.S.; Khademhosseini, A.; Dokmeci, M.R. Bioinks for 3D bioprinting: An overview. Biomater. Sci. 2018, 6, 915-946. [CrossRef]

22. Ouyang, L.; Yao, R.; Zhao, Y.; Sun, W. Effect of bioink properties on printability and cell viability for 3D bioplotting of embryonic stem cells. Biofabrication 2016, 8, 035020. [CrossRef]

23. Chung, J.H.Y.; Naficy, S.; Yue, Z.; Kapsa, R.; Quigley, A.; Moulton, S.E.; Wallace, G.G. Bio-ink properties and printability for extrusion printing living cells. Biomater. Sci. 2013, 1, 763-773. [CrossRef]

24. Ribeiro, A.; Blokzijl, M.M.; Levato, R.; Visser, C.W.; Castilho, M.; Hennink, W.E.; Vermonden, T.; Malda, J. Assessing bioink shape fidelity to aid material development in 3D bioprinting. Biofabrication 2017, 10, 014102. [CrossRef] [PubMed]

25. Gillispie, G.; Prim, P.; Copus, J.; Fisher, J.; Mikos, A.G.; Yoo, J.J.; Atala, A.; Lee, S.J. Assessment methodologies for extrusion-based bioink printability. Biofabrication 2020, 12, 022003. [CrossRef] [PubMed]

26. Kyle, S.; Jessop, Z.M.; Al-Sabah, A.; Whitaker, I.S. 'Printability' of Candidate Biomaterials for Extrusion Based 3D Printing: State-of-the-Art. Adv. Healthc. Mater. 2017, 6, 1700264. [CrossRef] [PubMed]

27. Zhao, Y.; Li, Y.; Mao, S.; Sun, W.; Yao, R. The influence of printing parameters on cell survival rate and printability in microextrusion-based 3D cell printing technology. Biofabrication 2015, 7, 045002. [CrossRef]

28. Townsend, J.M.; Beck, E.C.; Gehrke, S.H.; Berkland, C.J.; Detamore, M.S. Flow Behavior Prior to Crosslinking: The Need for Precursor Rheology for Placement of Hydrogels in Medical Applications and for 3D Bioprinting. Prog. Polym. Sci. 2019, 91, 126-140. [CrossRef]

29. Skardal, A.; Devarasetty, M.; Kang, H.W.; Mead, I.; Bishop, C.; Shupe, T.; Lee, S.J.; Jackson, J.; Yoo, J.; Soker, S.; et al. A hydrogel bioink toolkit for mimicking native tissue biochemical and mechanical properties in bioprinted tissue constructs. Acta Biomater. 2015, 25, 24-34. [CrossRef]

30. Natali, A.N.; Hart, R.T. Mechanics of Hard Tissues. In Integrated Biomaterials Science; Barbucci, R., Ed.; Springer: Boston, MA, USA, 2002; pp. 459-489.

31. Misch, C.E.; Qu, Z.; Bidez, M.W. Mechanical properties of trabecular bone in the human mandible: Implications for dental implant treatment planning and surgical placement. J. Oral Maxillofac. Surg. 1999, 57, 700-706, discussion 706-708. [CrossRef]

32. Zhang, S.; Wang, H. Current Progress in 3D Bioprinting of Tissue Analogs. SLAS Technol. 2019, $24,70-78$. [CrossRef]

33. Midha, S.; Dalela, M.; Sybil, D.; Patra, P.; Mohanty, S. Advances in three-dimensional bioprinting of bone: Progress and challenges. J. Tissue Eng. Regen. Med. 2019, 13, 925-945. [CrossRef]

34. Huang, Y.H.; Jakus, A.E.; Jordan, S.W.; Dumanian, Z.; Parker, K.; Zhao, L.; Patel, P.K.; Shah, R.N. Three-Dimensionally Printed Hyperelastic Bone Scaffolds Accelerate Bone Regeneration in Critical-Size Calvarial Bone Defects. Plast. Reconstr. Surg. 2019, 143, 1397-1407. [CrossRef]

35. Nam, S.Y.; Park, S.H. ECM Based Bioink for Tissue Mimetic 3D Bioprinting. Adv. Exp. Med. Biol. 2018, 1064, 335-353. [PubMed]

36. Mouser, V.H.M.; Levato, R.; Mensinga, A.; Dhert, W.J.A.; Gawlitta, D.; Malda, J. Bio-ink development for three-dimensional bioprinting of hetero-cellular cartilage constructs. Connect. Tissue Res. 2020, 61, 137-151. [CrossRef] [PubMed] 
37. Jakus, A.E.; Rutz, A.L.; Jordan, S.W.; Kannan, A.; Mitchell, S.M.; Yun, C.; Koube, K.D.; Yoo, S.C.; Whiteley, H.E.; Richter, C.P.; et al. Hyperelastic "bone": A highly versatile, growth factor-free, osteoregenerative, scalable, and surgically friendly biomaterial. Sci. Transl. Med. 2016, 8, 358ra127. [CrossRef] [PubMed]

38. Albrektsson, T.; Johansson, C. Osteoinduction, osteoconduction and osseointegration. Eur. Spine J. 2001, 10, S96-S101.

39. Rankin, E.B.; Giaccia, A.J.; Schipani, E. A central role for hypoxic signaling in cartilage, bone, and hematopoiesis. Curr. Osteoporos. Rep. 2011, 9, 46-52. [CrossRef]

40. Hao, Z.; Song, Z.; Huang, J.; Huang, K.; Panetta, A.; Gu, Z.; Wu, J. The scaffold microenvironment for stem cell based bone tissue engineering. Biomater. Sci. 2017, 5, 1382-1392. [CrossRef]

41. Kempen, D.H.; Yaszemski, M.J.; Heijink, A.; Hefferan, T.E.; Creemers, L.B.; Britson, J.; Maran, A.; Classic, K.L.; Dhert, W.J.; Lu, L. Non-invasive monitoring of BMP-2 retention and bone formation in composites for bone tissue engineering using SPECT/CT and scintillation probes. J. Control. Release 2009, 134, 169-176. [CrossRef]

42. van de Watering, F.C.; Molkenboer-Kuenen, J.D.; Boerman, O.C.; van den Beucken, J.J.; Jansen, J.A. Differential loading methods for BMP-2 within injectable calcium phosphate cement. J. Control. Release 2012, 164, 283-290. [CrossRef]

43. Hulsart-Billstrom, G.; Selvaraju, R.K.; Estrada, S.; Lubberink, M.; Asplund, V.; Bergman, K.; Marsell, R.; Larsson, S.; Antoni, G. Non-invasive tri-modal visualisation via PET/SPECT/muCT of recombinant human bone morphogenetic protein-2 retention and associated bone regeneration: A proof of concept. J. Control. Release 2018, 285, 178-186. [CrossRef]

44. Nair, K.; Gandhi, M.; Khalil, S.; Yan, K.C.; Marcolongo, M.; Barbee, K.; Sun, W. Characterization of cell viability during bioprinting processes. Biotechnol. J. 2009, 4, 1168-1177. [CrossRef]

45. Blaeser, A.; Campos, D.F.D.; Puster, U.; Richtering, W.; Stevens, M.M.; Fischer, H. Controlling Shear Stress in 3D Bioprinting is a Key Factor to Balance Printing Resolution and Stem Cell Integrity. Adv. Healthc. Mater. 2016, 5, 326-333. [CrossRef] [PubMed]

46. Forget, A.; Blaeser, A.; Miessmer, F.; Kopf, M.; Campos, D.F.D.; Voelcker, N.H.; Blencowe, A.; Fischer, H.; Shastri, V.P. Mechanically Tunable Bioink for 3D Bioprinting of Human Cells. Adv. Healthc. Mater. 2017, 6, 1700255. [CrossRef] [PubMed]

47. Tomov, M.L.; Theus, A.; Sarasani, R.; Chen, H.; Serpooshan, V. 3D Bioprinting of Cardiovascular Tissue Constructs: Cardiac Bioinks. In Cardiovascular Regenerative Medicine: Tissue Engineering and Clinical Applications; Serpooshan, V., Wu, S.M., Eds.; Springer International Publishing: Cham, Switzerland, 2019; pp. 63-77.

48. Ji, S.; Guvendiren, M. Recent Advances in Bioink Design for 3D Bioprinting of Tissues and Organs. Front. Bioeng. Biotechnol. 2017, 5, 23. [CrossRef] [PubMed]

49. Khazaei, M.; Salehi, E. Myocardial capillary density in normal and diabetic male rats: Effect of bezafibrate. Res. Pharm. Sci. 2013, 8, 119-123. [PubMed]

50. Hu, J.B.; Hu, D.A.; Buikema, J.W.; Chirikian, O.; Venkatraman, S.; Serpooshan, V.; Wu, S.M. Bioengineering of vascular myocardial tissue; a 3D bioprinting approach. Tissue Eng. Part A 2017, 23, S158-S159.

51. Huang, N.F.; Serpooshan, V.; Morris, V.B.; Sayed, N.; Pardon, G.; Abilez, O.J.; Nakayama, K.H.; Pruitt, B.L.; Wu, S.M.; Yoon, Y.S.; et al. Big bottlenecks in cardiovascular tissue engineering. Commun. Biol. 2018, 1, 199. [CrossRef]

52. Serpooshan, V.; Zhao, M.; Metzler, S.A.; Wei, K.; Shah, P.B.; Wang, A.; Mahmoudi, M.; Malkovskiy, A.V.; Rajadas, J.; Butte, M.J.; et al. Use of bio-mimetic three-dimensional technology in therapeutics for heart disease. Bioengineered 2014, 5, 193-197. [CrossRef]

53. Serpooshan, V.; Ruiz-Lozano, P. Ultra-rapid manufacturing of engineered epicardial substitute to regenerate cardiac tissue following acute ischemic injury. Methods Mol. Biol. 2014, 1210, 239-248.

54. Badylak, S.F.; Kochupura, P.V.; Cohen, I.S.; Doronin, S.V.; Saltman, A.E.; Gilbert, T.W.; Kelly, D.J.; Ignotz, R.A.; Gaudette, G.R. The use of extracellular matrix as an inductive scaffold for the partial replacement of functional myocardium. Cell Transpl. 2006, 1, S29-S40. [CrossRef]

55. Eitan, Y.; Sarig, U.; Dahan, N.; Machluf, M. Acellular cardiac extracellular matrix as a scaffold for tissue engineering: In vitro cell support, remodeling, and biocompatibility. Tissue Eng. Part C 2010, 16, 671-683. [CrossRef] 
56. Serpooshan, V.; Zhao, M.; Metzler, S.A.; Wei, K.; Shah, P.B.; Wang, A.; Mahmoudi, M.; Malkovskiy, A.V.; Rajadas, J.; Butte, M.J.; et al. The effect of bioengineered acellular collagen patch on cardiac remodeling and ventricular function post myocardial infarction. Biomaterials 2013, 34, 9048-9055. [CrossRef] [PubMed]

57. Suhaeri, M.; Subbiah, R.; Van, S.Y.; Du, P.; Kim, I.G.; Lee, K.; Park, K. Cardiomyoblast (h9c2) differentiation on tunable extracellular matrix microenvironment. Tissue Eng. Part A 2015, 21, 1940-1951. [CrossRef] [PubMed]

58. Serpooshan, V.; Hu, J.B.; Chirikian, O.; Hu, D.A.; Mahmoudi, M.; Wu, S.M. Chapter 8—4D Printing of Actuating Cardiac Tissue. In 3D Printing Applications in Cardiovascular Medicine; Al'Aref, S.J., Mosadegh, B., Dunham, S., Min, J.K., Eds.; Academic Press: Boston, MA, USA, 2018; pp. 153-162.

59. Hu, J.B.; Tomov, M.L.; Buikema, J.W.; Chen, C.; Mahmoudi, M.; Wu, S.M.; Serpooshan, V. Cardiovascular tissue bioprinting: Physical and chemical processes. Appl. Phys. Rev. 2018, 5, 041106. [CrossRef] [PubMed]

60. Chen, W.P.; Wu, S.M. Small molecule regulators of postnatal Nkx2.5 cardiomyoblast proliferation and differentiation. J. Cell Mol. Med. 2012, 16, 961-965. [CrossRef] [PubMed]

61. Lee, K.; Silva, E.A.; Mooney, D.J. Growth factor delivery-based tissue engineering: General approaches and a review of recent developments. J. R. Soc. Interface 2011, 8, 153-170. [CrossRef]

62. Ghazizadeh, Z.; Rassouli, H.; Fonoudi, H.; Alikhani, M.; Talkhabi, M.; Darbandi-Azar, A.; Chen, S.; Baharvand, H.; Aghdami, N.; Salekdeh, G.H. Transient Activation of Reprogramming Transcription Factors Using Protein Transduction Facilitates Conversion of Human Fibroblasts Toward Cardiomyocyte-Like Cells. Mol. Biotechnol. 2017, 59, 207-220. [CrossRef]

63. Cagavi, E.; Bartulos, O.; Suh, C.Y.; Sun, B.; Yue, Z.; Jiang, Z.; Yue, L.; Qyang, Y. Functional cardiomyocytes derived from Isl1 cardiac progenitors via Bmp4 stimulation. PLoS ONE 2014, 9, e110752. [CrossRef]

64. Degeorge, B.R., Jr.; Rosenberg, M.; Eckstein, V.; Gao, E.; Herzog, N.; Katus, H.A.; Koch, W.J.; Frey, N.; Most, P. BMP-2 and FGF-2 synergistically facilitate adoption of a cardiac phenotype in somatic bone marrow c-kit+/Sca-1+ stem cells. Clin. Transl. Sci. 2008, 1, 116-125. [CrossRef]

65. Hao, J.; Daleo, M.A.; Murphy, C.K.; Yu, P.B.; Ho, J.N.; Hu, J.; Peterson, R.T.; Hatzopoulos, A.K.; Hong, C.C. Dorsomorphin, a selective small molecule inhibitor of BMP signaling, promotes cardiomyogenesis in embryonic stem cells. PLoS ONE 2008, 3, e2904. [CrossRef]

66. Serpooshan, V.; Liu, Y.H.; Buikema, J.W.; Galdos, F.X.; Chirikian, O.; Paige, S.; Venkatraman, S.; Kumar, A.; Rawnsley, D.R.; Huang, X.; et al. Nkx2.5+ Cardiomyoblasts Contribute to Cardiomyogenesis in the Neonatal Heart. Sci. Rep. 2017, 7, 12590. [CrossRef]

67. Kreutziger, K.L.; Muskheli, V.; Johnson, P.; Braun, K.; Wight, T.N.; Murry, C.E. Developing vasculature and stroma in engineered human myocardium. Tissue Eng. Part A 2011, 17, 1219-1228. [CrossRef] [PubMed]

68. Bax, N.A.; van Marion, M.H.; Shah, B.; Goumans, M.J.; Bouten, C.V.; van der Schaft, D.W. Matrix production and remodeling capacity of cardiomyocyte progenitor cells during in vitro differentiation. J. Mol. Cell Cardiol. 2012, 53, 497-508. [CrossRef] [PubMed]

69. Fan, D.; Takawale, A.; Lee, J.; Kassiri, Z. Cardiac fibroblasts, fibrosis and extracellular matrix remodeling in heart disease. Fibrogenesis Tissue Repair 2012, 5, 15. [CrossRef] [PubMed]

70. Lindsey, M.L.; Iyer, R.P.; Zamilpa, R.; Yabluchanskiy, A.; DeLeon-Pennell, K.Y.; Hall, M.E.; Kaplan, A.; Zouein, F.A.; Bratton, D.; Flynn, E.R.; et al. A Novel Collagen Matricryptin Reduces Left Ventricular Dilation Post-Myocardial Infarction by Promoting Scar Formation and Angiogenesis. J. Am. Coll. Cardiol. 2015, 66, 1364-1374. [CrossRef]

71. Ungerleider, J.L.; Johnson, T.D.; Rao, N.; Christman, K.L. Fabrication and characterization of injectable hydrogels derived from decellularized skeletal and cardiac muscle. Methods 2015, 84, 53-59. [CrossRef]

72. Porter, K.E.; Turner, N.A. Cardiac fibroblasts: At the heart of myocardial remodeling. Pharmacol. Ther. 2009, 123, 255-278. [CrossRef]

73. Nian, M.; Lee, P.; Khaper, N.; Liu, P. Inflammatory cytokines and postmyocardial infarction remodeling. Circ. Res. 2004, 94, 1543-1553. [CrossRef]

74. Ong, C.S.; Fukunishi, T.; Zhang, H.; Huang, C.Y.; Nashed, A.; Blazeski, A.; DiSilvestre, D.; Vricella, L.; Conte, J.; Tung, L.; et al. Biomaterial-Free Three-Dimensional Bioprinting of Cardiac Tissue using Human Induced Pluripotent Stem Cell Derived Cardiomyocytes. Sci. Rep. 2017, 7, 4566. [CrossRef]

75. Gao, L.; Kupfer, M.E.; Jung, J.P.; Yang, L.; Zhang, P.; da Sie, Y.; Tran, Q.; Ajeti, V.; Freeman, B.T.; Fast, V.G.; et al. Myocardial Tissue Engineering With Cells Derived From Human-Induced Pluripotent Stem Cells and a Native-Like, High-Resolution, 3-Dimensionally Printed Scaffold. Circ. Res. 2017, 120, 1318-1325. [CrossRef] 
76. Giacomelli, E.; Bellin, M.; Sala, L.; van Meer, B.J.; Tertoolen, L.G.; Orlova, V.V.; Mummery, C.L. Three-dimensional cardiac microtissues composed of cardiomyocytes and endothelial cells co-differentiated from human pluripotent stem cells. Development 2017, 144, 1008-1017. [CrossRef]

77. Pati, F.; Jang, J.; Ha, D.H.; Kim, S.W.; Rhie, J.W.; Shim, J.H.; Kim, D.H.; Cho, D.W. Printing three-dimensional tissue analogues with decellularized extracellular matrix bioink. Nat. Commun. 2014, 5, 3935. [CrossRef] [PubMed]

78. Gil, C.J.; Tomov, M.L.; Theus, A.S.; Cetnar, A.; Mahmoudi, M.; Serpooshan, V. In Vivo Tracking of Tissue Engineered Constructs. Micromachines 2019, 10, 474. [CrossRef] [PubMed]

79. Kajbafzadeh, A.M.; Tafti, S.H.A.; Mokhber-Dezfooli, M.R.; Khorramirouz, R.; Sabetkish, S.; Sabetkish, N.; Rabbani, S.; Tavana, H.; Mohseni, M.J. Aortic valve conduit implantation in the descending thoracic aorta in a sheep model: The outcomes of pre-seeded scaffold. Int. J. Surg. 2016, 28, 97-105. [CrossRef]

80. Mazzocchi, A.; Devarasetty, M.; Huntwork, R.; Soker, S.; Skardal, A. Optimization of collagen type I-hyaluronan hybrid bioink for 3D bioprinted liver microenvironments. Biofabrication 2018, 11, 015003. [CrossRef] [PubMed]

81. Lee, J.W.; Choi, Y.J.; Yong, W.J.; Pati, F.; Shim, J.H.; Kang, K.S.; Kang, I.H.; Park, J.; Cho, D.W. Development of a 3D cell printed construct considering angiogenesis for liver tissue engineering. Biofabrication 2016, 8, 15007. [CrossRef] [PubMed]

82. Vijayavenkataraman, S.; Yan, W.C.; Lu, W.F.; Wang, C.H.; Fuh, J.Y.H. 3D bioprinting of tissues and organs for regenerative medicine. Adv. Drug Deliv. Rev. 2018, 132, 296-332. [CrossRef] [PubMed]

83. Lee, S.-J.; Esworthy, T.; Stake, S.; Miao, S.; Zuo, Y.Y.; Harris, B.T.; Zhang, L.G. Advances in 3D Bioprinting for Neural Tissue Engineering. Adv. Biosyst. 2018, 2, 1700213. [CrossRef]

84. Anderson, P.A. Clinical Applications of 3D Printing. Spine 2017, 42, S30-S31. [CrossRef]

85. Tappa, K.; Jammalamadaka, U. Novel Biomaterials Used in Medical 3D Printing Techniques. J. Funct. Biomater. 2018, 9, 17. [CrossRef]

86. Badylak, S.F.; Gilbert, T.W. Immune response to biologic scaffold materials. Semin. Immunol. 2008, 20, 109-116. [CrossRef]

87. Pati, F.; Ha, D.-H.; Jang, J.; Han, H.H.; Rhie, J.-W.; Cho, D.-W. Biomimetic 3D tissue printing for soft tissue regeneration. Biomaterials 2015, 62, 164-175. [CrossRef] [PubMed]

88. van Belleghem, S.; Torres, L., Jr.; Santoro, M.; Mahadik, B.; Wolfand, A.; Kofinas, P.; Fisher, J.P. Hybrid 3D Printing of Synthetic and Cell-Laden Bioinks for Shape Retaining Soft Tissue Grafts. Adv. Funct. Mater. 2020, 30, 1907145. [CrossRef]

89. Godoi, F.C.; Prakash, S.; Bhandari, B.R. 3d printing technologies applied for food design: Status and prospects. J. Food Eng. 2016, 179, 44-54. [CrossRef]

90. Visser, J.; Peters, B.; Burger, T.J.; Boomstra, J.; Dhert, W.J.; Melchels, F.P.; Malda, J. Biofabrication of multi-material anatomically shaped tissue constructs. Biofabrication 2013, 5, 035007. [CrossRef] [PubMed]

91. Jing, X.; Mi, H.Y.; Huang, H.X.; Turng, L.S. Shape memory thermoplastic polyurethane (TPU)/poly(epsilon-caprolactone) (PCL) blends as self-knotting sutures. J. Mech. Behav. Biomed. Mater. 2016, 64, 94-103. [CrossRef]

92. Kim, B.S.; Jang, J.; Chae, S.; Gao, G.; Kong, J.-S.; Ahn, M.; Cho, D.-W. Three-dimensional bioprinting of cell-laden constructs with polycaprolactone protective layers for using various thermoplastic polymers. Biofabrication 2016, 8, 035013. [CrossRef]

93. Lee, J.W.; Kim, J.Y.; Cho, D.W. Solid Free-form Fabrication Technology and Its Application to Bone Tissue Engineering. Int. J. Stem Cells 2010, 3, 85-95. [CrossRef]

94. Du, B.L.; Zeng, C.G.; Zhang, W.; Quan, D.P.; Ling, E.A.; Zeng, Y.S. A comparative study of gelatin sponge scaffolds and PLGA scaffolds transplanted to completely transected spinal cord of rat. J. Biomed. Mater. Res. A 2014, 102, 1715-1725. [CrossRef]

95. Putnam, D. Drug delivery: The heart of the matter. Nat. Mater. 2008, 7, 836-837. [CrossRef]

96. Zhang, Z.; Jin, Y.; Yin, J.; Xu, C.; Xiong, R.; Christensen, K.; Ringeisen, B.R.; Chrisey, D.B.; Huang, Y. Evaluation of bioink printability for bioprinting applications. Appl. Phys. Rev. 2018, 5, 041304. [CrossRef]

97. He, Y.; Yang, F.; Zhao, H.; Gao, Q.; Xia, B.; Fu, J. Research on the printability of hydrogels in 3D bioprinting. Sci. Rep. 2016, 6, 29977. [CrossRef] [PubMed]

98. Hölzl, K.; Lin, S.; Tytgat, L.; van Vlierberghe, S.; Gu, L.; Ovsianikov, A. Bioink properties before, during and after 3D bioprinting. Biofabrication 2016, 8, 032002. [CrossRef] [PubMed] 
99. Jang, D.; Kim, D.; Moon, J. Influence of fluid physical properties on ink-jet printability. Langmuir 2009, 25, 2629-2635. [CrossRef] [PubMed]

100. Xu, T.; Jin, J.; Gregory, C.; Hickman, J.J.; Boland, T. Inkjet printing of viable mammalian cells. Biomaterials 2005, 26, 93-99. [CrossRef]

101. Saunders, R.E.; Derby, B. Inkjet printing biomaterials for tissue engineering: Bioprinting. Int. Mater. Rev. 2014, 59, 430-448. [CrossRef]

102. Murphy, S.V.; Atala, A. 3D bioprinting of tissues and organs. Nat. Biotechnol. 2014, 32, 773-785. [CrossRef]

103. Peltola, S.M.; Melchels, F.P.; Grijpma, D.W.; Kellomaki, M. A review of rapid prototyping techniques for tissue engineering purposes. Ann. Med. 2008, 40, 268-280. [CrossRef]

104. Yu, Y.; Zhang, Y.; Martin, J.A.; Ozbolat, I.T. Evaluation of cell viability and functionality in vessel-like bioprintable cell-laden tubular channels. J. Biomech. Eng. 2013, 135, 91011. [CrossRef]

105. Kim, S.H.; Yeon, Y.K.; Lee, J.M.; Chao, J.R.; Lee, Y.J.; Seo, Y.B.; Sultan, M.T.; Lee, O.J.; Lee, J.S.; Yoon, S.I.; et al. Precisely printable and biocompatible silk fibroin bioink for digital light processing 3D printing. Nat. Commun. 2018, 9, 1620. [CrossRef]

106. Ning, L.; Chen, X. A brief review of extrusion-based tissue scaffold bio-printing. Biotechnol. J. 2017, 12, 1600671. [CrossRef]

107. Ning, L.; Yang, B.; Mohabatpour, F.; Betancourt, N.; Sarker, M.; Papagerakis, P.; Chen, X. Process-induced cell damage: Pneumatic versus screw-driven bioprinting. Biofabrication 2020, 12, 025011. [CrossRef] [PubMed]

108. Ning, L.; Betancourt, N.; Schreyer, D.J.; Chen, X. Characterization of cell damage and proliferative ability during and after bioprinting. ACS Biomater. Sci. Eng. 2018, 4, 3906-3918. [CrossRef]

109. Panwar, A.; Tan, L.P. Current status of bioinks for micro-extrusion-based 3D bioprinting. Molecules 2016, 21, 685. [CrossRef]

110. Zuidema, J.M.; Rivet, C.J.; Gilbert, R.J.; Morrison, F.A. A protocol for rheological characterization of hydrogels for tissue engineering strategies. J. Biomed. Mater. Res. Part B 2014, 102, 1063-1073. [CrossRef] [PubMed]

111. Gao, T.; Gillispie, G.J.; Copus, J.S.; Seol, Y.-J.; Atala, A.; Yoo, J.J.; Lee, S.J. Optimization of gelatin-alginate composite bioink printability using rheological parameters: A systematic approach. Biofabrication 2018, 10, 034106. [CrossRef] [PubMed]

112. Soltan, N.; Ning, L.; Mohabatpour, F.; Papagerakis, P.; Chen, X. Printability and cell viability in bioprinting alginate dialdehyde-gelatin scaffolds. ACS Biomater. Sci. Eng. 2019, 5, 2976-2987. [CrossRef]

113. Ning, L.; Zhu, N.; Mohabatpour, F.; Sarker, M.; Schreyer, D.J.; Chen, X. Bioprinting Schwann cell-laden scaffolds from low-viscosity hydrogel compositions. J. Mater. Chem. B 2019, 7, 4538-4551. [CrossRef]

114. Ning, L.; Sun, H.; Lelong, T.; Guilloteau, R.; Zhu, N.; Schreyer, D.J.; Chen, D.X. 3D bioprinting of scaffolds with living Schwann cells for potential nerve tissue engineering applications. Biofabrication 2018, 10, 035014. [CrossRef]

115. Zehnder, T.; Sarker, B.; Boccaccini, A.R.; Detsch, R. Evaluation of an alginate-gelatine crosslinked hydrogel for bioplotting. Biofabrication 2015, 7, 025001. [CrossRef]

116. Rajaram, A.; Schreyer, D.; Chen, D. Bioplotting alginate/hyaluronic acid hydrogel scaffolds with structural integrity and preserved schwann cell viability. 3D Print. Addit. Manuf. 2014, 1, 194-203. [CrossRef]

117. Gao, G.; Cui, X. Three-dimensional bioprinting in tissue engineering and regenerative medicine. Biotechnol. Lett. 2016, 38, 203-211. [CrossRef] [PubMed]

118. Ouyang, L.; Highley, C.B.; Rodell, C.B.; Sun, W.; Burdick, J.A. 3D printing of shear-thinning hyaluronic acid hydrogels with secondary cross-linking. ACS Biomater. Sci. Eng. 2016, 2, 1743-1751. [CrossRef]

119. Ouyang, L.; Highley, C.B.; Sun, W.; Burdick, J.A. A generalizable strategy for the 3D bioprinting of hydrogels from nonviscous photo-crosslinkable inks. Adv. Mater. 2017, 29, 1604983. [CrossRef] [PubMed]

120. Göhl, J.; Markstedt, K.; Mark, A.; Håkansson, K.; Gatenholm, P.; Edelvik, F. Simulations of 3D bioprinting: Predicting bioprintability of nanofibrillar inks. Biofabrication 2018, 10, 034105. [CrossRef] [PubMed]

121. Paxton, N.; Smolan, W.; Böck, T.; Melchels, F.; Groll, J.; Jungst, T. Proposal to assess printability of bioinks for extrusion-based bioprinting and evaluation of rheological properties governing bioprintability. Biofabrication 2017, 9, 044107. [CrossRef]

122. Lee, A.; Hudson, A.; Shiwarski, D.; Tashman, J.; Hinton, T.; Yerneni, S.; Bliley, J.; Campbell, P.; Feinberg, A. 3D bioprinting of collagen to rebuild components of the human heart. Science 2019, 365, 482-487. [CrossRef]

123. Zhu, N.; Li, M.; Cooper, D.; Chen, X. Development of novel hybrid poly(l-lactide)/chitosan scaffolds using the rapid freeze prototyping technique. Biofabrication 2011, 3, 034105. [CrossRef] 
124. Ravindran, S.; Kotecha, M.; Huang, C.-C.; Ye, A.; Pothirajan, P.; Yin, Z.; Magin, R.; George, A. Biological and MRI characterization of biomimetic ECM scaffolds for cartilage tissue regeneration. Biomaterials 2015, 71, 58-70. [CrossRef]

125. Tanter, M.; Fink, M. Ultrafast imaging in biomedical ultrasound. IEEE Trans. Ultrason. Ferroelectr. Freq. Control 2014, 61, 102-119. [CrossRef]

126. Yao, T.; Deng, Z.; Zhang, K.; Li, S. A method to predict the ultimate tensile strength of 3D printing polylactic acid (PLA) materials with different printing orientations. Compos. Part B 2019, 163, 393-402. [CrossRef]

127. Matai, I.; Kaur, G.; Seyedsalehi, A.; McClinton, A.; Laurencin, C.T. Progress in 3D bioprinting technology for tissue/organ regenerative engineering. Biomaterials 2020, 226, 119536. [CrossRef]

128. Knowlton, S.; Anand, S.; Shah, T.; Tasoglu, S. Bioprinting for neural tissue engineering. Trends Neurosci. 2018, 41, 37-46. [CrossRef] [PubMed]

129. Chen, X.; Li, M.; Ke, H. Modeling of the flow rate in the dispensing-based process for fabricating tissue scaffolds. J. Manuf. Sci. Eng. 2008, 130, 021003. [CrossRef]

130. Cheng, L.H.H.; Yao, B.; Hu, T.; Cui, X.L.; Shu, X.; Tang, S.J.; Wang, R.; Wang, Y.H.; Liu, Y.F.; Song, W.; et al. Properties of an alginate-gelatin-based bioink and its potential impact on cell migration, proliferation, and differentiation. Int. J. Biol. Macromol. 2019, 135, 1107-1113. [CrossRef] [PubMed]

131. Schacht, K.; Jungst, T.; Schweinlin, M.; Ewald, A.; Groll, J.; Scheibel, T. Biofabrication of Cell-Loaded 3D Spider Silk Constructs. Angew. Chem. Int. Edit. 2015, 54, 2816-2820. [CrossRef] [PubMed]

132. Skardal, A.; Murphy, S.V.; Devarasetty, M.; Mead, I.; Kang, H.W.; Seol, Y.J.; Zhang, Y.S.; Shin, S.R.; Zhao, L.; Aleman, J.; et al. Multi-tissue interactions in an integrated three-tissue organ-on-a-chip platform. Sci. Rep. 2017, 7, 16. [CrossRef] [PubMed]

133. Serban, M.A.; Skardal, A. Hyaluronan chemistries for three-dimensional matrix applications. Matrix Biol. 2019, 78, 337-345. [CrossRef]

134. Zhou, X.; Cui, H.T.; Nowicki, M.; Miao, S.D.; Lee, S.J.; Masood, F.; Harris, B.T.; Zhang, L.G. Three-Dimensional-Bioprinted Dopamine-Based Matrix for Promoting Neural Regeneration. ACS Appl. Mater. Interfaces 2018, 10, 8993-9001. [CrossRef]

135. Lin, Z.F.; Wu, M.M.; He, H.M.; Liang, Q.F.; Hu, C.S.; Zeng, Z.W.; Cheng, D.L.; Wang, G.C.; Chen, D.F.; Pan, H.B.; et al. 3D Printing of Mechanically Stable Calcium-Free Alginate-Based Scaffolds with Tunable Surface Charge to Enable Cell Adhesion and Facile Biofunctionalization. Adv. Funct. Mater. 2019, $29,14$. [CrossRef]

136. Peak, C.W.; Singh, K.A.; Adlouni, M.; Chen, J.; Gaharwar, A.K. Printing Therapeutic Proteins in 3D using Nanoengineered Bioink to Control and Direct Cell Migration. Adv. Healthc. Mater. 2019, 8, 10. [CrossRef]

137. Choudhury, D.; Tun, H.W.; Wang, T.Y.; Naing, M.W. Organ-Derived Decellularized Extracellular Matrix: A Game Changer for Bioink Manufacturing? Trends Biotechnol. 2018, 36, 787-805. [CrossRef] [PubMed]

138. Lee, H.; Han, W.; Kim, H.; Ha, D.H.; Jang, J.; Kim, B.S.; Cho, D.W. Development of Liver Decellularized Extracellular Matrix Bioink for Three-Dimensional Cell Printing-Based Liver Tissue Engineering. Biomacromolecules 2017, 18, 1229-1237. [CrossRef] [PubMed]

139. Rabinarayan, P. Cross-Linked Hydrogel for Pharmaceutical Applications: A Review. Adv. Pharm. Bull. 2017, 7, 515-530.

140. Malda, J.; Visser, J.; Melchels, F.P.; Juengst, T.; Hennink, W.E.; Dhert, W.J.A.; Groll, J.; Hutmacher, D.W. 25th Anniversary Article: Engineering Hydrogels for Biofabrication. Adv. Mater. 2013, 25, 5011-5028. [CrossRef]

141. Highley, C.B.; Rodell, C.B.; Burdick, J.A. Direct 3D Printing of Shear-Thinning Hydrogels into Self-Healing Hydrogels. Adv. Mater. 2015, 27, 5075-5079. [CrossRef]

142. Hinton, T.J.; Jallerat, Q.; Palchesko, R.N.; Park, J.H.; Grodzicki, M.S.; Shue, H.J.; Ramadan, M.H.; Hudson, A.R.; Feinberg, A.W. Three-dimensional printing of complex biological structures by freeform reversible embedding of suspended hydrogels. Sci. Adv. 2015, 1, e1500758. [CrossRef]

143. Lenzi, F.; Sannino, A.; Borriello, A.; Porro, F.; Mensitieri, G. Probing the degree of crosslinking of a cellulose based superabsorbing hydrogel through traditional and NMR techniques. Polymer 2003, 44, 1577-1588. [CrossRef]

144. Sannino, A.; Pappada, S.; Madaghiele, M.; Maffezzoli, A.; Ambrosio, L.; Nicolais, L. Crosslinking of cellulose derivatives and hyaluronic acid with water-soluble carbodiimide. Polymer 2005, 46, 11206-11212. [CrossRef]

145. Flory, P.J. Principles of Polymer Chemistry; Cornell University Press: Ithaca, NY, USA, 1953. 
146. Koetting, M.C.; Peters, J.T.; Steichen, S.D.; Peppas, N.A. Stimulus-responsive hydrogels: Theory, modern advances, and applications. Mat. Sci. Eng. R 2015, 93, 1-49. [CrossRef]

147. Kim, S.W.; Bae, Y.H.; Okano, T. Hydrogels: Swelling, drug loading, and release. Pharm. Res. 1992, 9, $283-290$. [CrossRef]

148. Sun, Y.; Wang, Q. Modeling and simulations of multicellular aggregate self-assembly in biofabrication using kinetic Monte Carlo methods. Soft Matter 2013, 9, 2172-2186. [CrossRef]

149. Yildirimer, L.; Seifalian, A.M. Three-dimensional biomaterial degradation-Material choice, design and extrinsic factor considerations. Biotechnol. Adv. 2014, 32, 984-999. [CrossRef] [PubMed]

150. Gunatillake, A.P. 2-Nondegradable synthetic polymers for medical devices and implants. In Biosynthetic Polymers for Medical Applications; Woodhead Publishing: Sawston, UK, 2016; pp. 33-62.

151. Zhang, H.; Zhou, L.; Zhang, W. Control of Scaffold Degradation in Tissue Engineering: A Review. Tissue Eng. Part B 2014, 20, 492-502. [CrossRef] [PubMed]

(C) 2020 by the authors. Licensee MDPI, Basel, Switzerland. This article is an open access article distributed under the terms and conditions of the Creative Commons Attribution (CC BY) license (http://creativecommons.org/licenses/by/4.0/). 